Kekerasan pada Anak.... (Tri Sella, Melinda P.S Jaya)

\title{
KEKERASAN PADA ANAK USIA DINI (STUDY KASUS PADA ANAK UMUR 6-7 TAHUN DI KERTAPATI)
}

\author{
Oleh: Tri Sella Margareta, Melinda Puspita Sari Jaya \\ (Universitas PGRI Palembang) \\ Email: Trisellam@gmail.com
}

\begin{abstract}
Abstrak
Tujuan penelitian ini untuk mengetahui dan mendeskripsikan dampak kekerasan orang tua terhadap anak usia dini. Metode penelitian yang digunakan dalam penelitian ini yaitu metode study kasus, objek penelitian ini adalah anak yang mengalami kekerasan dari orang tua terdiri dari 1 (satu) orang. Data yang dianalisi adalah observasi, wawancara, dokumetasi mengenai "Kekerasan Pada Anak Usia Dini"'Study Kasus Pada Anak Usia 6-7 Tahun Di Daerah Kertapati. Hasil penelitian ini memiliki dampak buruk bagi anak yaitu kesehatan mental maupun fisik anak pertumbuhan dan perkembangan anak akan berbeda dengan anak pada umumnya. Dampak yang dialami anak dari kekerasan yang dilakukan oleh orangtua adalah kurangnya motivasi atau harga diri, mengembangkan perilaku agresif atau jadi pemarah pada saat dilingkungan diluar rumah dan menjadi pendiam pada saat di dalam rumah, sering tidak napsu makan, dan merasakan sakit pada fisik setelah menerima kekerasan dari orang tua.
\end{abstract}

Kata Kunci: Kekerasan, Anak Usia Dini

\section{VIOLENCE IN CHILDREN OF EARLY AGE (CASE STUDY IN CHILDREN AGE 6-7 YEARS IN KERTAPATI)}

\begin{abstract}
The purpose of this study was to determine and describe the impact of parental violence on early childhood. The research method used in this research is the case study method, the object of this research is children who experience violence from parents consisting of 1 (one) person. The data analyzed were observations, interviews, documentation about "Violence in Early Childhood" (Case Study of Children 6-7 Years Old in Kertapati. The results of this study had a negative impact on children, namely mental and physical health of the child's growth and development. different from children in general.The impact experienced by children of violence committed by parents is lack of motivation or self-esteem, develop aggressive behavior or become angry when the environment outside the home and become quiet when inside the house, often lack of appetite, and feel physical pain after receiving violence from parents.
\end{abstract}

Keywords: Violence, Early Childhood 


\section{A. PENDAHULUAN}

Orangtua memiliki peranan dalam tumbuh kembang anak karena orang tua selain sebagai pemimpin juga sebagai guru pertama, pembimbing, pengajar, fasilitator, dan sebagai teladan bagi anak-anaknya.Anak adalah perwujudan cinta kasih orang tua, dan orang tua untuk menjadi pelindungnya. Dengan memiliki anak mengubah banyak hal dalam kehidupan orang tua, dan pada akhirnya mau tidak mau, suka atau tidak, orang tua dituntut untuk siap menjadi orang tua yang harus dapat mempersiapkan anak-anak agar dapat menjalankan kehidupan masa depan mereka dengan baik.

Dalam perannya sebagai guru pertama, orang tua harus memperhatikan masa depan anak-anak agar dapat menjadi penerus bangsa. Sekolah merupakan penunjang bagi orang tua dalam mempersiapkan masa depan anak agar anak dapat memperoleh wawasan, dunia baru, hidup bersosial, dan ilmu-ilmu yang diterima. Orang tua sebagai pendidik memiliki kewajiban dalam memberikan pengalaman pertama kepada anak. Pengalaman di keluarga akan menentukan kehidupan anak kedepannya. Selain orang tua, peran orang lain disekitar anak juga merupakan penting dikehidupan anak. Maka dari itu memberi pengalaman dan contoh yang baik merupakan tugas penting orang disekitar anak.

Menjadi orang tua harus siap memikul tanggung jawab untuk mendidik, membesarkan anak dan memberikan kasih sayang yang cukup agar anak tumbuh menjadi pribadi dewasa yang bermoral, sehat dan cerdas. Anak merupakan belahan jiwa gambaran dan cerminan masa depan, aset keluarga, agama, bangsadan negara. Anak adalah titipan anugrah terindah, yang seharusnya di didik dengan penuh kasih dan cinta. Tetapi banyak sekali orang tua kandung maupun orang tua angkat yang tidak menjaga titipannya tapi malah menyiksa anak tersebut.

Kekerasan pada anak masih banyak terjadi ditengah masyarakat, mulai dari kekerasan, pembunuhan, penganiayaan dan bentuk tindakan kriminal lainya yang berpengaruh negatif bagi kejiwaan anak. Seharusnya seorang anak diberi pendidikan yang tinggi, serta didukung dengan kasih sayang keluarga agar 
jiwanya tidak terganggu. Hal ini terjadi karena banyak orang tua menganggap kekerasan pada anak adalah hal yang wajar. Mereka beranggapan kekerasan adalah bagian dari mendisiplinan anak. Mereka lupa bahwa orang tua adalah orang yang paling bertanggung jawab dalam mengupayakan kesejahteraan, perlindungan peningkatan, kelangsungan hidup dan mengoptimalkan tumbuh kembang anak. Keluarga adalah tempat pertama kali anak belajar mengenal aturan yang berlaku yang sengaja maupun tidak sengaja yang ditunjukan untuk mencederai atau merusak anak, baik berupa serangan fisik maupun mental.

Kekerasan terhadap anak adalah semua bentuk tindakan menyakitkan secara fisik atau emosional, penyalahgunaan seksual, trafiking, penelantaran, eksploitasi yang mengakibatkan cidera/kerugian nyata ataupun potensial terhadap kesehatan anak, kelangsungan hidup anak, tumbuh kembang anak atau martabat anak, yang dilakukan dalam konteks hubungan tanggung jawab, kepercayaan atau kekuasaan.

Kekerasan terhadap anak dapat terjadi kapan saja dan dimana saja termasuk pada saat di rumah, di tempat bermain bahkan di sekolah.Padahal sekolah merupakan tempat dimana anak menerima pendidikan moral, etika dan akademik, bahkan menjadi rumah kedua bagi anak.Namun, kenyataannya justru di sebagian sekolah terjadi kasus kekerasan. Baik yang dilakukan oleh teman sepermainan, senior, guru atau penjaga kebersihan sekolah.

Kesadaran orang tua mengenai dampak buruk dari hukuman kekerasan masihlah rendah, hal ini dipengaruhi adanya banyak faktor seperti kurangnya pengetahuan mengenai kekerasan, adanya tradisi kekerasan, sehingga masalah psikologis. Namun pada umumnya orang tua merasa bahwa kekerasan satu-satu nya solusi untuk mengasuh dan mendidik anak. Padahal cara lebih baik mengasuh dan mendidik anak yakni dengan mengganti hukuman dengan konsekuensi. Sebab dengan konsekuensi anak dapat belajar mengoreksi kesalahan dengan kesadaran sendiri.

Berdasarkan Penelitian tentang kekerasan pada anak yang telah dilakukan oleh Mahmudi (2018) dengan judul “Child Abuse Kekerasan Pada Anak Dalam 
Perspektif Pendidikan Islam”. Penelitian tersebut mengungkapkan bahwa mendidik anak sebaik mungkin tidak menggunakan tindakan kekerasan, karena jika tidak mengerti dalam penggunaan kekerasan untuk mendidik anak tersebut, kemungkinan justru akan menimbulkan dampak yang buruk.

Anak Indonesia pada usia 6-12 tahun paling sering mengalami kekerasan seksual (33\%) dan emosional (28,8\%), dibandingkan dengan kekerasan yang bersifat fisik $(24,1 \%)$. Ruang kekerasan terhadap anak sebagian besar terjadi di rumah (129 kasus), selanjutnya di jalanan (79 kasus), sekolah (10 kasus), lembaga keagamaan (2 kasus), sektor perekonomian (21 kasus). Kekerasan seksual juga terjadi tidak hanya di rumah $(48,7 \%)$, tapi juga di tempat umum $(6,1 \%)$, sekolah $(4,1 \%)$, tempat kerja $(3,0 \%)$, lain-lain $(0,4 \%)$.

Lain halnya yang terjadi dilapangan, anak yang berinisial $\mathrm{R}$ yang mengalami kekerasan dariorang tua di daerah kertapati kecamatan seberang ulu 1 kota Palembang.Memiliki latar belakang keluarga yang lengkap, anak tersebut merupakan anak semata wayangdari orang tua yang memiliki latar belakang pendidikan yang kurang dan kondisi ekonomi yang rendah. Anak tersebut juga kurang mendapatkan perhatian dari kedua orang tuanya. Orang tuanya sering membentak dan mencacimaki didepan umum sehingga tetangga sekitar dapat menyaksikan pertengkaran orang tua dan anak.

Orang tua tersebut memberikan hukuman kepada anak dalam bentuk kekerasan seperti mencubit, menampar, mendorong dan memukul, sehingga hal tersebut berdampak padaanak. Mungkin faktor yang mendukung orang tua melakukan kekerasan pada anak karena kurangnya pengetahuan bagaimana menjadi orang tua. Padahal keterlibatan orang tua terhadap proses pengasuhan anak sangatlah penting karena menentukan tumbuh kembang anak. Orang tua yang mendidik anak dengan cara memberikan kekerasan fisik maupun psikis akan berdampak pada anak kedepannya. Berdasarkan fenomena tersebut, penulis tertarik untuk melakukan penelitian terkait "Kekerasan Pada Anak Usia Dini”(Study Kasus Pada Anak Usia 6-7 Tahun Di Daerah Kertapati). 
Kekerasan pada anak usia dini merupakan tindakan yang dapat merusak perkembangan anak, baik secara fisik, psikis, maupun seksual. yang dapat memperngaruhi perkembangan kehidupan masa depan anak. Rusmil dalam Huraerah (2018:52) dijelaskan bahwa penyebab atau resiko terjadinya kekerasan dan penelantaran terhadap anak dibagi ke dalam 3 (tiga) faktor, yaitu orang tua/keluarga, faktor lingkungan sosial/komunikasi, dan faktor anak sendiri.

Menurut Suyanto (2010:59) Kekerasan dapat berakibat buruk bagi perkembangan diri anak. Kekerasan pada anak dalam rumah tangga itu sendiri memiliki bentuk yang bermacam-macam.

1. Pengabaian fisik biasanya terjadi karena kondisi ekonomi keluarga yang kurang baik, sehingga orang tua cenderung mengakibatkan kebutuhan anak akan makanan yang bergizi, pakaian, dan perawatan kesehatan. Namun demikian, bukan berati pengabaian fisik ini tidak terjadi dalam keluarga yang mampu. Biasanya dalam keluarga mampu, pengabaian fisik ini merupakan bentuk hukuman atas "kenakalan" anak.

2. Kekerasan psikologis dapat muncul dalam bentuk makian, penghinaan, mengejek anak di depan orang lain. Misalnya ketika anak menjatuhkan piring, lalu orang tua berteriak “anak sialan!"atau, dalam bentuk yang lebih halus seperti orang tua mengejek anak nya di depan umum karena ia gagal menjadi juara kelas, "anak saya emang bodoh kok. Wajar kalo nggak juara"

3. Orang tua juga tidak sadar juga sering melakukan kekrasan fisik secara sengaja. Misalnya ketika anak rewal, orang tua kemudian menjewer atau mencubit anaknya supaya diam. Terkadang alasan dibalik tindakan ini cenderung egois, seperti malu dilihat orang karena berisik, atau taku dianggap tidak bisa mengajar anak dengan baik.

4. Bentuk terakhir merupakan kekerasan seksual pada anak kekerasan sesksul, apabila jika dilakukan oleh orang tuanya sendiri, akan berakibatkan sangat buruk pada anak, misalnya mereka akan merasa rendah diri, mengalami kesulitan konsentrasi, kecemasan berkepanjangan bahkan masalah-masalah kesehatan fisik. 
Wahana Didaktika Vol. 18 No.2 Mei 2020 : 171-180

\section{B. METODOLOGI PENELITIAN}

Kekerasan pada anak usia dini adalah semua bentuk tindakan menyakitkan secara fisik maupun emosional dan kekerasan seksualpada anak, yang mengakibatkan dampak fisik yang bersifat traumatis pada anak yang dilakukkan oleh orang terdekat seperti keluarga, dan lingkungan sekitar maupun orang yang tidak dikenal yang mengakibatkan gejala penurunan moral. Bentuk kekerasan yang diukur di dalam penelitian ini adalah berupa tindakan-tindakan kekerasan secara fisik, psikis, dan seksual.

Faktor yang mempengaruhi terjadinya kekerasan pada usia dini yaitu faktor orang tua yang tidak mengetahui tentang pola asuh yang baik trehadap anak, faktor lingkungn social yaitu rendahnya ekonomi ditengah masyarakat dan faktor anak itu sendiri misalnya prilaku menyimpang. Dampak buruk bagi anak yaitu kesehatan mental maupun fisik anak akan menurun selain itu pertumbuhan dan perkembangan anak akan berbeda dengan anak pada umumnya.

\section{HASIL PENELITIAN DAN PEMBAHASAN}

Kekerasan pada anak usia dini adalah semua bentuk tindakan menyakitkan secara fisik maupun emosional dan kekerasan seksual pada anak, yang mempunyai dampak fisik yang bersifat traumatis pada anak yang dilakukkan oleh orang terdekat seperti keluarga, dan lingkungan sekitar maupun orang yang tidak dikenal yang mengakibatkan gejala penurunan moral.

Dalam penelitian ini, tindakan kasar atau kekerasan yang dilakukan ibu Y terhadap $\mathrm{R}$ sangatlah tidak baik mengingat $\mathrm{R}$ adalah anak usia emas yang sepatutnya mendapatkan pengasuhan baik dan kasih sayang terhadap orang tuanya. Kejadian-kejadian yang ditemukan peneliti terhadap objek penelitian berdasarkan hasil observasi dan wawancara yaitu cacian, makian, bahkan pukulan membuat $\mathrm{R}$ menjadi anak yang penakut, tidak percaya diri, minder, dan bahkan berpengaruh pada kesehatan fisik dan mental R.

Sejalan dengan pendapat Lickona (2015 :20) tindakan kekerasan atau anarki adalah tindakan yang mengakibatkan gejala penurunan moral, akibat dari 
penurunan moral tersebut karna terlalu sering terjadinya kekerasan secara psikis. Menurutnya dilapangan beberapa anak yang mengalami kekerasan secara psikis hal tersebut akan melemahkan pemahaman mengenai pembentukan karakter.

Pengasuhan Ibu Y terhadap $\mathrm{R}$ yang menggunakan sikap kasar dan tidak pernah mendengar cerita atau pendapat dari $\mathrm{R}$ membuat $\mathrm{R}$ menjadi anak yang berkecil hati karena merasa tidak pernah mendapatkan kasih sayang dari orang tuanya. Ibu Y yang melakukan tindakan kekerasan dalam pengasuhan R, membuat $\mathrm{R}$ berbeda dari anak pada umumnya. Anak-anak yang pada umumnya merasakan kebahagiaan dengan usia dini mereka melalui bermain seakan tidak pernah dialami R. Penelitian ini sejalan dengan penelitian yang dilakukan olehMahmudi (2018) yang membahas mengenai "child abuse kekerasan pada anak dalam perspektif pendidikan islam" penelitian dilakukan di lampung, hasil dari penelitian menemukansekitar 19,4\% kasus kekerasan anak dalam pengasuhan.

Orang tua sebagai pendidik utama didalam keluarga perlu mengetahui apa dan bagaimana seorang anak. Setiap anak memiliki keunikan dan kelebihan tersendiri.Orang tua sebagai pendidik pertama dan utama bagi anakanaknyatentunya harus memberikan pendidikan dan pengasuhan yang baik. Pendidikan yang diberikanberupa nilai-nilai, keyakinan, akhlak dan pengetahuan. Selain itu fungsi pendidik dikeluarga diantaranya sebagai fungsi biologis, sebagai fungsi ekonomi, fungsi kasih sayang, fungsi pendidikan, fungsi perlindungan, fungsi sosialisasi anak, fungsi rekreasi, fungsi status keluarga dan fungsi agama.

\section{Bentuk Kekerasan Orang Tua Terhadap Anak Usia Dini}

Berdasarkan hasil penelitian yang didapat, keluarga ibu Y merupakan keluarga yang menerapkan pengasuhan dengan bentuk kekerasan terhadap $R$ dimana menurut ibu $\mathrm{Y}$ dengan menerapkan tindakan keras terhadap $\mathrm{R}$ akan membuat $\mathrm{R}$ menjadi anak yang patuh dan penurut, tetapi malah sebaliknya penerapan pengasuhan dengan tindakan kekerasan berdampak buruk bagi kesehatan fisik maupun psikis terhadap R. Ini terlihat dari kondisi R yang setiap melakukan apapun selalu berujung tangisan. Dibentak di depan umum, dicaci 
maki bahkan dipukul. Beberapa bentuk kekerasan yang dialami oleh $\mathrm{R}$ yaitu kekerasan fisik seperti $\mathrm{R}$ sering mendapatkan hukuman fisik dari ibu $\mathrm{Y}$ berupa pukulan, dorongan, dicubit, dijewer, ditampar, dan dijambak. Selain itu R juga mengalami bentuk kekerasan psikis seperti sering diperlakukan ibu Y dengan ocehan atau dimarah dan dibentak didepan umum yang mengakibatkan $\mathrm{R}$ merasa malu dan terpojok.

\section{Faktor Yang Mempengaruhi Terjadinya Kekerasan Anak Usia Dini}

Fenomena yang terjadi dewasa ini banyak sekali orang tua yang menghukum anak secara fisik, orang tua menghukum tanpa pengetahuan yang benar dan tepat serta dalam keadaan emosi yang tinggi sehingga hukuman berdampak buruk pada anak. Orang tua sebagai pendidik hendaknya memahami sifat dasar yang dimiliki anak-anaknya. Anak harus dimotivasi untuk selalu mengerjakan perbuatan baik, dan mencegah atau menghindarkan anak dari perbuatan buruk. Kekerasan tersebut dilatarbelakangi oleh beberapa faktor seperti orang tua, lingkungan dan faktor anak itu sendiri.

Seperti yang terjadi pada $\mathrm{R}$, faktor yang membuat ibu $\mathrm{Y}$ melakukan kekerasan pada $\mathrm{R}$ adalah kondisi ekonomi yang rendah. Ibu Y dalam kehidupan sehari-hari menjadi tulang punggung keluarga dan mengurus $\mathrm{R}$ sendirian. Lalu faktor selanjutnya adalah kurangnya pengetahuan ibu $\mathrm{Y}$ dalam mendidik anak sehingga kesalahan yang dilakukan $\mathrm{R}$ selalu diselsaikan dengan kekerasan. Hal sejalan dengan pendapat Agustin dkk (2018: 5) mengatakan bahwa Keadaan yang juga turut mempengaruhi terjadinya tindak kekerasan adalah latar belakang keluarga dan pola pengasuhan orang tua. Faktor lain yang mendorong terjadinya kekerasan pada anak adalah persepsi yang salah tentang cara mendidik anak. Sebagian orang tua dan guru berpendapat bahwa mencubit dan berkata-kata dengan suara keras adalah cara terbaik untuk mendidik anak agar anak menurut. Hal ini merupakan kesalahan besar dalam mendidik anak sekaligus bentuk ketidakmampuan orang tua dan guru dalam mengkomunikasikan sesuatu yang baik dan tidak baik kepada anak. 
Kekerasan pada Anak.... (Tri Sella, Melinda P.S Jaya)

\section{Dampak Kekerasan Terhadap Anak}

Ibu Y menerapkan pengasuhan dengan bentuk kekerasan terhadap $\mathrm{R}$ tanpa mengetahui dampak kedepannya terhadap R, seperti ibu Y melontarkan kata kasar, membentak dan mencaci maki $\mathrm{R}$ dalam keadaan emosi yang selalu melihat bahwa $\mathrm{R}$ lah yang salah dan langsung memberikan hukuman. Tindakan kekerasan yang dilakukan Ibu Ykepada R berdampak pada fisik dan psiskis. Dampak fisik yang dialami oleh $\mathrm{R}$ sering merasakan sakit setelah mengalami kekerasan dari Ibu $\mathrm{Y}$, sedengkan dampak psikis yang diterima oleh $\mathrm{R}$ sesuai dengan penelitian yang telah dilakukan adalah $\mathrm{R}$ tampak kurangnya motivasi pada saat pergi kesekolah karena Ibu tidak mendukung dan memberi semangat.

Berdasarkan hasil penelitian di atas, dikatakan bahwa orang tua melakukan usaha dalam mencegah dampak negatif dari perlakukan kekerasan terhadap anak. Usaha tersebut yaitu memberikan pengetahuan agama kepada anak, dan menyemangati anak supaya mau mendengarkan orang tua dengan memberi hadiah saat anak menurut dan menaati kesepakatan dan hukuman saat anak yang dapat digunakan oleh orang tua dalam mencegah dampak negatif tersebut. Orang tua harus mengetahui pengasuhan dan pemberian pendidikan yang terbaik untuk anak-anaknya. Cari tau apakah perlakukan yang diberikan terhadap anak sudah baik atau belum.

Dalam penelitian ini ibu $\mathrm{Y}$ menyikapi kesalahan $\mathrm{R}$ dengan langsung menuduh $\mathrm{R}$ yang bersalah dan langsung memberikan hukuman tanpa mencari tahu atau mendengar penjelaan $\mathrm{R}$, sebagai orang tua menyikapi dengan baik kesalahan anak dengan melakukan pengarahan kepada anak sangatlah penting.

Memotivasi anak dengan ganjaran tidak selalu berupa pemberian materi kepada anak. Begitu pula dengan hukuman, hukuman tidak harus berupa pukulan sebagai akibat dari perbuatan yang seharusnya tidak dilakukan anak. Orang tua harus lebih memahami apa tepat anak yang berbuat baik harus diberi ganjaran berupa materi, sedangkan anak yang melakukan kesalahn harus dihukum dengan hukuman fisik. Hukuman fisik akan berdampak tidak baik terhadap pertumbuhan dan perkembangan anak. 


\section{SIMPULAN}

Berdasarkan hasil penelitian dapat ditarik kesimpulan bahwa kekerasan orangtua terhadap anak usia dini tersebut memiliki dampak buruk bagi anak yaitu kesehatan mental maupun fisik anak akan menurun selain itu pertumbuhan dan perkembangan anak akan berbeda dengan anak pada umumnya. Dampak yang dialami R dari kekerasan yang dilakukan oleh Ibu Y adalah kurangnya motivasi atau harga diri, mengembangkan perilaku agresif atau jadi pemarah pada saat dilingkungan di luar rumah dan menjadi pendiam pada saat di dalam rumah terutama di dekat Ibu Y, sering tidak napsu makan, dan merasakan sakit pada fisik setelah menerima kekerasan dari Ibu Y.

Dalam mengatasi kekerasan orang tua terhadap anak, sebagai orang tua yang cerdas, orang tua harus memberikan pengalaman, pengasuhan dan pendidikan yang terbaik untuk anaknya, tentunya orang tua harus mengetahui pola asuh yang baik diterapkan orang tua dalam meberikan pengasuhan terhadap anak haruslah dengan ilmu bukan hanya dengan pengalaman saja.

\section{DAFTAR PUSTAKA}

Agustin, dkk. (2018). Analysis Typical Of Violence In Children, Effect And The Underlying Factors. Dalam jounnal Ilmiah PGTK PAUD dan DIKMAS Vol. 13, No. 1, Juni 2018.

Huraerah, A. (2018). Kekerasan terhadap Anak. Bandung: Penerbit Nuasa Cendikia.

Lickona, Thomas. (2015). Educating For Character. Jakarta: Bumi Aksara.

Mahmudi. I, N. (2018). Child Abuse Kekerasan pada Anak dalam Perspektif Pendidikan Islam. Skripsi. Uin Raden Intan Lampung.

Suyanto, B. (2014). Masalah sosial anak. Jakarta: Penerbit prenada media. 